\title{
ВКЛАД ВЫДАЮЩЕГОСЯ АВИАКОНСТРУКТОРА А. С. МОСКАЛЕВА В РАЗВИТИЕ СОВЕТСКОГО САМОЛЕТОСТРОЕНИЯ
}

В представленной статье рассматриваются основные направления деятельности выдающегося советского авиаконструктора - А. С. Москалева, который стал достойным преемником и продолжателем эстафеты отечественной школы авиастроения, перешедшей к нему от И. И. Сикорского через Н. Н. Поликарпова. Автором детально представлены достижения А. С. Москалева, который стал автором более 40 новаторских конструкций летательных аппаратов, среди которых ряд самолетов под названием “САМ» - самолет Александра Москалева. А. С. Москалев был родоначальником дельтавидного крыла малого удлинения, позволившего мировой авиации совершить резкий качественный скачок в развитии сверхзвуковой и гиперзвуковой авиации. В статье подчеркивается, что любая его работа, будь то спортивный самолет, десантный планер или истребитель, отличалась изобретательностью инженерной мысли, была отмечена высоким профессионализмом и, как следствие, была одной из наиболее эффективных в своем классе в мире.

В статье удалось проследить, как идеи А. С. Москалева легли в основу разработки ряда самолетов, ставших одной из составляющих стратегического паритета
Советского Союза, среди которых был суперсамолет М-50 конструктора В. Н. Мясищева, а также сверхзвуковые стратегические бомбардировщики ОКБ Туполева Ту-22, М-3 и Ту-160, до сих пор стоящие на вооружении Воздушно-космических сил России, и ряд других. А. С. Москалеву принадлежит и авторство идеи воздушно-космического орбитального самолета, что неоднократно подчеркивал главный конструктор советского воздушно-космического самолета «Буран» Г. Е. ЛозиноЛозинский.

Новизной работы является компслексное изучение профессиональной биографии А. С. Москалева. Известный лишь узкому кругу специалистов, А. С. Москалев внес огромный вклад в развитие отрасли. Исследование существенно расширяет представления о советском самолетостроение и особенностях его развития. Благодаря широкому кругу источников, в том числе архивных, достижения советского авиаконструктора вписаны в контекст 1930-х гг., через перипетии его судьбы показан трагизм исторической эпохи.

Ключевые слова: А. С. Москалев, Н. Н. Поликарпов, И. И. Сикорский, самолеты «САМ», советская авиация, советское самолетостроение.

V. Gagin

\section{CONTRIBUTION OF THE OUTSTANDING AIRCONSTRUCTOR A. S. MOSKALEV IN THE DEVELOPMENT OF THE SOVIET AERONAUTICAL ENGINEERING}

This article discusses the main activities of the outstanding Soviet aircraft designer - A. S. Moskalev, who became a worthy successor of the national school of aeronautical engineering, which passed to him from I. Sikorsky through N. N. Polikarpov. The author presents A. S. Moskalev's achievements in detail. He was the author of more than 40 innovative aircraft designs, among which a number of aircraft called "SAM" are Alexander Moskalev's aircraft. A. S. Moskalev was the founder of the deltoid wing of small elongation, which allowed world aviation to make a sharp qualitative leap in the development of supersonic and hypersonic aviation. The article emphasizes that any of his work, whether it be a sports aircraft, a landing glider or a fighter, was distinguished by the ingenuity of engineering, was noted for its high professionalism and, as a result, was one of the most effective in its class in the world.

The author traced how the ideas of A. S. Moskalev formed the basis for the development of a number of aircraft, which became one of the components of the strategic parity of the Soviet Union, among which was the super-plane M-50 designer V. N. Myasishchev, as well as the supersonic strategic bombers of the Tupolev Design Bureau Tu-22, M-3 and Tu-160, still in service with the Russian Aerospace Forces, and a number of others. A. S. Moskalev also belongs to the authorship of the idea of an aerospace orbital aircraft, which was repeatedly emphasized by the chief designer of the Soviet aerospace aircraft Buran G. E. Lozino-Lozinsky

The novelty of the work is a comprehensive study of the professional biography of A. S. Moskalev. Known only to a narrow circle of specialists, A. S. Moskalev made a huge contribution to the development of the industry. The study significantly expands the understanding of Soviet aircraft construction and the features of its development. Thanks to a wide range of sources, including archival ones, the achievements of the Soviet aircraft designer are inscribed in the context of the 1930s, through the vicissitudes of his fate the tragedy of the historical era is shown.

Key words: A. S. Moskalev, N. N. Polikarpov, I. I. Sikorsky, SAM aircraft, Soviet aeronautical engineering, Soviet aviation. 
Вистории российской авиациихорошо известны имена выдающихся авиаконструкторов: Н. Н. Поликарпов, С. В. Ильюшин, П. О. Сухой, А. Н. Туполев, А. И. Микоян, М. Л. Миль, Н. И. Камов, А. С. Яковлев. Люди, интересующиеся авиацией, хорошо знают и помнят С. А. Лавочкина, О. К. Антонова, В. Ф. Болховитинова, В. М. Петлякова, В. М. Мясищева, М. И. Гуревича, А. А. Архангельского. Имена А. С. Москалева, К. А. Калинина, И. В. Четверикова, Г М. Бериева, Р. Л. Бартини, В. Г. Ермолаева, Д. С. Маркова и некоторых других, к сожалению, не столь знакомы российской общественности [3].

Цель нашей статьи - рассказать об одном из таких малоизвестных авиаконструкторов, сыгравщих большую роль в развитии отечественного авиастроения, а именно - о Москалеве Александре Сергеевиче.

Научная актуальность работы связана с изучением биографии и деятельности А. С. Москалева в рамках исторической биографики, позволяющей вписать отдельно взятую историческую фигуру в контекст эпохи и выявить вклад авиаконструктора в развитие отрасли. Изучение деятельности А. С. Москалева позволяет по достоинству оценить его разработки в области авиации, превосходство его изобретений по сравнению с подобными наработками признанных мэтров советского авиастроения в довоенный период, что только повышает актуальность представленной статьи

Межвоенный период истории СССР вполне можно определить основным советским лозунгом первых пятилеток: «Догнать и перегнать!» Преодолевая огромные трудности на пути коммунистического созидания, народы России строили социализм. Одной из важнейших составляющих этого процесса было создание мощной и современной боевой авиации [22, с. 4-11].

$\mathrm{Ee}$ созданием занимались многие авиаконструкторы, но слава и признание пришли не к каждому из них. Например, советский сверхдальний самолет АНТ-37 «Родина» (для рекордного перелета женского экипажа Валентины Гризодубовой) сконструировал П. О. Сухой; главный конструктор скоростного бомбардировщика (СБ) - АНТ-40, ставшего символом и эмблемой советской авиации благодаря участию в крупнейших предвоенных локальныхвойнах и консрликтах-А. А. Архангельский, а тяжелый «бомбовоз» АНТ-42 (ТБ-7) спроектировал и внедрил в производство В.М. Петляков, при том, что аббревиатура «АНТ» расшифровывается, как «Андрей Николаевич Туполев». Волевые и организаторские качества Туполева делали его, скорее, преуспевающим «менеджером», нежели выдающимся авиаконструктором, поэтому многие талантливые инженеры-самолетостроители так и остались в его тени. История показывает, что сам Туполев, с его жестким, авторитарным стилем управления является, как теперь принято говорить, «брендом» советского самолетостроения. Лишь немногие, такие, как П. О. Сухой и В. М. Мясищев, сумели-таки вырваться из-под его «опеки» и возглавить в послевоенный период собственные ОКБ [28, с. 24-26]. Эгоцентричный А. Н. Туполев не мог им простить такую самостоятельностьдо конца своей жизни и делал все, чтобы помешать им в их работе. Более того, еще до Великой Отечественной войны А. Н. Туполев сделал все, чтобы убрать с дороги таких опасных для его КБ конкурентов, как В. Ф. Болховитинова, К. А. Калинина, Д. П. Григоровича, Н. Н. Поликарпова. Для К. А. Калинина эта травля закончилась смертью в воронежской тюрьме НКВД [27, л. 278-296].

В случае с КБ А. С. Яковлева мы имеем, как минимум, одного впоследствии знаменитого авиаконструктора - О. К. Антонова, который слишком долго оставался в тени своего начальника. В то же время, на вполне резонном основании, можем с глубоким сожалением констатировать его (Яковлева) более чем успешные интриги и демарши против своих коллег - руководителей самолетостроительных КБ Н. Н. Поликарпова, С. А. Лавочкина $[10$, с. 33-36], А. С. Москалева [20], которые объективно обернулись для советской авиации крупномасштабными проблемами и серьезно задержали прогресс в отечественном самолетостроении

Николай Николаевич Поликарпов, истребители которого И-5, И-15, И-16 и И-153 были основными в ВВС РККА в 1930-е гг., испытал гонения и со стороны А. И. Микояна: для создания КБ Микояна и Гуревича распоряжениями Народного комиссариата авиационной промышленности (НКАП) у Поликарпова забрали практически всю материальную базу и лучших его специалистов М. Гуревича, В. Ромодина, Н. И. Андрианова, а всего более 80 человек. Об этом писал сам Н. Н. Поликарпов в письме в наркомат $[14$, с. $216-$ 219].

Несмотря на все препятствия, более чем плодотворная деятельность Николая Николаевича на ниве советского самолетостроения была, как минимум, постоянным стимулом недобросовестной конкуренции с использованием связей и служебного положения одновременно у Микояна, Туполева, Яковлева и, как показывают современные исследования, даже у Ильюшина. Поликарпов сумел осуществить сложнейшие в тех условиях мероприятия по доводке истребителя И-185 и его испытаниям в строевом полку на Калининском фронте. Многие специалисты считают эту машину лучшим истребителем Второй мировой войны по обе стороны фронта. В истребителе И-185 были заложены самые передовые, инновационные идеи, какие только существовали на тот момент в мировой авиационной мысли [23, с. 155$]$

Высочайший профессионализм и истинно гражданская позиция патриота Поликарпова, прожившего всего 52 года, вызывает искреннее восхищение. От напряжения всех сил и нервов, в невыносимых условиях колоссального морального давления Николай Николаевич не смог выжить просто физически - он умер от рака в 1944 г

Непредвзятого исследователя неприятно удивляет и поражает тот факт, что большое количество высших советских ответственных должностных лиц Наркомата обороны, Наркомата 
авиапромышленности не защитили Поликарпова, чей довоенный вклад в валютную «выручку» СССР от продажи его истребителей в зарубежные страны был огромен и не имел равных среди конструкторов как самолетов, так и любой другой боевой техники и вооружения, от недостойных конкурентов.

Так, на 1 января 1938 г. Советский Союз поставил республиканской Испании 550 боевых самолетов, из них 460 машин (истребители, разведчики и легкие бомбардировщики) конструкции Н. Н. Поликарпова [26]. Китаю, сражавшемуся с японскими оккупантами, СССР в качестве интернациональной помощи перегнал 985 машин, из которых около 650 - конструкции Н. Н. Поликарпова [27]. Таких примеров можно привести много. На его самолетах летали тогда даже в Афганистане.

Н. Н. Поликарпов, «интеллигент из бывших» и «Поп», прекрасно знавший очень ограниченные возможности отечественной авиационной промышленности того времени, прекрасно проявил себя как патриот и гражданин. Он многократно проявлял активную и принципиальную позицию в вопросах экономии материалов и использования в технологии самых простых и недорогих методов для упрощения процессов конструирования и сборки своих самолетов. Поликарпов всегда помнил, за счет чего и за счет кого создавались новые авиазаводы и моторостроительные предприятия [32]. Именно этот авиаконструктор является определяющим этапом генезиса, вехой в становлении А. С. Москалева.

Для понимания истоков феномена А. C. Москалева необходимо сказать несколько слов и - И. И. Сикорском, который стоит особняком в истории отечественной авиации. Во времена СССР упоминали, что он - создатель знаменитого бомбардировщика «Илья Муромец", но только в годы перестройки российской авиационной общественности стали известны подробности биографии и творчества в эмиграции великого русского инженера, масштабы его огромного научно-технического наследия.

В то время, когда в остальном мире едва-едва осваивали первые аэропланы, И. И. Сикорский, будучи еще студентом, построил в Киеве работоспособный вертолет. Убедившись в том, что для вертолета пригодного по удельной мощности мотора тогда не было, Игорь Иванович стал проектировать и строить самолеты. Он добился на этом пути самых высоких мировых достижений, открыв эру массовых трансокеанских перелетов (его пассажирские и транспортные гидропланы не имели равных). В области вертолетостроения он стал на долгие десятилетия законодателем мировой «моды» в проектировании лучших в мире геликоптеров военного и гражданского назначения [16].

Вот такие прекрасные традиции продолжил и преумножил Александр Сергеевич Москалев, как преемник эстафеты русской школы самолетостроения, перешедшей к нему от И. И. Сикорского через Н. Н. Поликарпова, сохраняя присущую всем троим подлинную русскую интеллигентность
Слово «эстафета» здесь - не для красного словца, а полностью оправдано историческими обстоятельствами. Напомню, что Н. Н. Поликарпов работал начальником производства самолетов Сикорского, в том числе и знаменитых гигантов «Илья Муромец», на Русско-Балтийском вагоноремонтном заводе, а А. С. Москалев, будучи впоследствии инженером-расчетчиком и начальником КБ на заводе № 23 в Ленинграде, производившем поликарповскую «летающую парту" самолет У-2, имел возможность очень внимательно и тщательно ознакомиться с работами Н. Н. Поликарпова, а также другого выдающегося отечественного авиационного конструктора Д. П. Григоровича [11].

Уместно подчеркнуть, что Москалев имел прямое отношение к производству самолетов У-2, благодаря которым в Советском Союзе в 1930-е годы авиационный спорт, включая парашютизм, стали массовыми. Так, на 1 января 1935 г. авиация Осоавиахима имела 630 самолетов, их них 550 самолетов $(87.3 \%)$ были самолеты У-2 [7, л. 193]. Если в 1933 г. с самолетов прыгнуло 1.200 парашютистов, то в 1935 г. - 20.000, подавляющее большинство которых прыгнуло с самолета У-2 [9, л. 57]. На 1 января 1941 г. авиация Осоавиахима насчитывала 4.151 самолет, из них $3.768(90.8 \%)$ составляли самолеты У-2. На этой технике готовилось 9.100 бойцов-парашютистов, 45.000 пилотов первоначального обучения для школ ВВС, в программу подготовки которых входило не менее 2-х прыжков с парашютом, а также ряд других специалистов [8, л. 76, 71]. Эти фракты убедительно говорят о том, что массовость авиаспорта и парашютизма, в том числе обеспечили, прежде всего, самолеты У-2.

Александр Москалев называл свои самолеты «САМ» - самолет Александра Москалева. Это было предопределено тем, что практически всю основную работу главного конструктора, главного инженера и директора завода, выпускавшего его самолеты, он всегда делал сам.

В условиях хронической нехватки авиационных двигателей рассчитывать на более мощный мотор было трудно [25]. Поэтому в качестве основного двигателя для своих «САМов» он выбрал 120 - а затем 140-сильный мотор М-11, которые выпускал Воронежский моторный завод №16. «Движок» был маломощный, зато надежный, дешевый и простой - «народный», как и самолеты А. С. Москалева [1].

Талант Москалева проявился и в том, что он был создателем прекрасных пассажирских самолетов, оснащенных воронежским маломощным мотором М-11. Для своих конструкций он использовал самые простые, недорогие материалы фанеру и перкаль (пропитанную аэролаком ткань для обшивки).

Дерево и фанера - эти дешевые конструкционные материалы Москалев выбирал совершенно осмысленно. Как гражданин, он понимал, насколько дефицитен был алюминий в РСФСР в то время. В этом смысле он подобен велико- 
му англичанину Джефффри де Хэвилленду с его знаменитым детищем - цельнодеревянным бомбардировщиком «Москито». Де Хевилленд был поставлен в условия применения фанеры по причине морской блокады Британии германскими подводными лодками. Тем не менее, он сумел создать настоящий деревянный шедевр мирового самолетостроения [36].

Как уже упоминалось выше, Александр Сергеевич свою карьеру авиатора начинал в северной столице. Несколько нереализованных проектов в Ленинграде обернулись после переезда А. С. Москалева в Воронеж постройкой легкого пассажирского и спортивно-туристического пятиместного самолета с великолепными характеристиками CAM-5.

Его тут же запустили в серию, а молодой авиаконструктор, слегка модифицировав САМ-5, начал готовиться к установлению мирового рекорда. Это был настоящий вызов столице: воронежский экипаж на воронежском самолете с воронежским мотором установил мировой рекорд дальности полета - за 19 часов 50 минут пролетел более 4000 километров. Это был международный рекорд дальности по прямой, более чем на 500 км превысивший достижение американцев Бука и Билленграфа (3.318 км) [30, с. 397]. Мировой рекорд, установленный в 1937 г., продержался более 12 лет.

Специалистов особенно привлекали высокая весовая отдача и легкость управления - САМ-5 2бис был настолько хорош, что Франция, в которой было великолепно развито авиастроение, прислала заказ сразу на 250 машин Москалева [34, c. 554]

Строить их не стали - московские конкуренты «отписались» наверх, что, в Воронеже нет условий, производственных мощностей для выпуска такой крупной серии. Самого конструктора при этом никто ни о чем не спросил, а между тем А. С. Москалев наладил производство этих машин поагрегатно, т.е. примерно по тому же принципу, по которому французы сегодня в Тулузе собирают «Эйрбасы» из комплектующих, привезенных со всей Европы: на мебельной фабрике изготавливали силовой набор фюзеляжа и крыльев САМ-5, а в мастерских авиатехникума собирали готовые аэропланы - санитарный, пассажирский и даже «исполкомовский» (летающий лимузин для начальства) [31, с. 6-9].

Но серийного производства этого самолета не было, так как ленинградский завод №23 был базой другого авиаконструктора - Яковлева. Директор завода Балабанов, не желая портить отношения с замнаркома, отказался перестраивать производство. И это, подчеркнем, даже после того, как из Франции пришел валютный заказ на москалевские самолеты.

Мнение современных авиаконструкторов легкомоторной авиации едино: А. С. Москалев в своих конструкциях настолько тонко умел сочетать профиль и удлинение крыла при заданных параметрах фрюзеляжа, что это давало его машинам уникальную управляемость и такие взлетно-поса- дочные характеристики, которые и сегодня могут служить эталоном [35].

Таким же примером удивительного, из ряда вон выходящего понимания сути авиационного проектирования и практического применения аэродинамики, может служить и «Летающая танкетка" конструкции Москалева САМ-23. Эта машина превосходит все мыслимые и дерзновенные ожидания. Весовая отдача - более $40 \%$ на грани франтастики! Только представьте себе: сверхмалый и сверхлегкий деревянный «штурмовичок» Москалева был построен все с тем же 100-сильным мотором М-11, но мог нести такую же бомбовую нагрузку, как и знаменитый «летающий танк» Ил-2 с двигателем в 10 раз мощнее. По сравнению с ильюшинским Ил-2 «бронированная блоха», как еще называли этот построенный в двух экземплярах штурмовик Москалева, обладала полнейшим превосходством в тактико-технических характеристиках: в шесть раз более тяжелый и дорогой Ил-2 имел точно такое же, как у САМ-23, стрелково-пушечное вооружение и бомбовую нагрузку. В серию самолеты не пошли только из-за негосударственного подхода к отечественному самолетостроению и обороне страны нескольких крупных московских деятелей Наркомата авиационной промышленности [24]. Только косность и недобросовестность авиационных отечественных чиновников не позволили развить до массового серийного производства этот проект, эфффективность и оригинальность которого ставит Москалева вровень с признанными мировыми мэтрами, мастерами неординарных и нестандартных решений в области проектирования летательных аппаратов.

К сожалению, не обладал Александр Сергеевич, интеллигент из семьи дореволюционных врачей из воронежской «Глубинки», необходимыми для выживания в условиях бюрократического административного засилья «большевистской хваткой» и «пробивными» способностями, а тогдашние чины от советской авиации, ставшие впоследствии генералами и Героями социалистического труда, государственного подхода не проявили и не дали выдающемуся конструкторскому уму «зеленую улицу» на пользу Отечеству.

Воронежцы могут гордиться тем, что наряду с известнейшими авиаконструкторами, обласканными советской властью и народной славой, в их городе жил и работал великий, но по ряду причин менее известный, авиаконструктор А. С. Москалев. Но и сегодня в Воронеже нет ни улицы имени А. С. Москалева, ни памятника выдающемуся земляку, ни его музея.

А в Заводоуковске, куда эвакуировали его ОКБ №31 в годы Великой Отечественной войны и где за три года Москалев построил авиазавод № 499 - градообразующее предприятие, его помнят по-настоящему: и памятник установили, и каждый год проводят замечательные краеведческие конференции, где обязательно присутствуют разнообразные и интересные доклады и материалы об А. С. Москалеве [18, с. 102-107]. 
В Сибире его авиазавод по заданию партии строил десантные планеры конструкции О. Антонова и десантные кабины для подвески под бомбардировщики ДБ-3 и Ил-4 для воздушно-десантных войск. После выпуска серии антоновских 7-местных планеров, Москалев написал Антонову письмо с приложением двух листков расчетов, предлагая строить на базе антоновского 14-местный планер в тех же габаритах. О. К. Антонов нашел расчеты настолько убедительными, что немедленно прислал Москалеву расписку с разрешением.

Обеспечив производство модернизированных планеров, Москалев спроектировал, построил и испытал большой планер САМ-23 (название перешло от «затертого наверху», по выражению самого Москалева, штурмовика - «летающей танкетки»). Планер не имел равных в СССР: перевозил 20 бойцов или легковой автомобиль. Он был построен по сложной для расчетов (Москалев умел их делать), но весьма перспективной схеме, по которой годы спустя будут построены тяжелый французский транспортный самолет «Норатлас» и многоцелевой самолет ОКБ Сухого C-80 [19, c. 181]

А. С. Москалев необычайно многогранен, как новатор. Мало кто знает, что в Заводоуковске на его заводе собирали планеры самого современного в то время, если не самого передового на тот момент, советского ракетного самолета БИ-1 и что Валерий Чкалов (еще до Великой отечественной войны) собирался облететь «вокруг шарика» именно на самолете Александра Москалева, с установкой дизеля на рекордный самолет AHT-25 (РД) [21, c. 3]

Когда по произволу советских номенклатурных бюрократов самолетам Москалева, даже серийным, не хватило места на авиазаводе №18, они строились в мастерских авиатехникума и на мебельной фабрике. Даже здесь Александр Сергеевич воспитывал все новые и новые кадры, в том числе и для воронежского авиазавода.

Штатных пилотов для его рекордных машин также не нашлось - ими стали военные летчики 11-й тяжелой авиабригады и Воронежского аэроклуба Осоавиахима. Один из них - А. Н. Гусаров, стал шеф-пилотом москалевского ОКБ и верным другом авиаконструктора на всю жизнь [15, с. 106]

Несмотря на откровенное торможение его работы, в 1939-1941 гг. А. С. Москалев занимался созданием учебно-тренировочного и боевого (истребителя) самолетов. Носовая опора его истребителя (это был чуть ли не единственный тогда в СССР самолет с передней стойкой шасси) укладывалась под двигатель. Самолеты отличались предельной простотой линий, сочетающихся в правильные аэродинамические формы И снова к самому передовому, на тот момент, проекту истребителя САМ-13 было проявлено "сдержанное» отношение. Но, невзирая на это самолет был построен, прошел продувку в трубе Т-101 ЦАГИ и буквально накануне войны сдан на летные испытания. Даже с неубираемым шасси истребитель, пилотируемый Н. Д. Фиксоном, показал скорость 560 км/ч. Другие конструкторы добивались такого результата с убранным шасси и при мощности мотора свыше 1000 л.с. Например опытный истребитель А. С. Яковлева И-26, будущий Як-1, не мог превысить рубеж 520 км/час без аварийного перегрева силовой установки. Фактически достигнутое значение скорости истребителя Москалева составило 607 км/ч. Как нужен был такой быстрый и недорогой истребитель в годы Великой Отечественной войны! [20, с. 99-105].

Как подлинный, а не номенклатурный, лидер и руководитель, А. С. Москалев не ждал «милостей от природы» - он сам ковал необходимые для проектирования и строительства самолетов кадры. Учебные заведения авиационного профиля в Воронеже обеспечивали весь спектр подготовки специалистов для развития науки и производства. И в этой работе чуть ли не главную роль играл сам А. С. Москалев [13].

Как начальник счетно-конструкторского отдела (СКО) авиазавода №18, Москалев, видя, что предприятию катастрофически не хватает грамотных специалистов, организует и возглавляет кафедру аэромеханики в Воронежском государственном университете и там преподает аэродинамику и аэромеханику. Как авиаконструктор-практик, находящийся на самом переднем крае самолетостроения, он испытывал огромные трудности с получением времени для экспериментов на московских и ЦАГовских (в Раменском) аэродинамических трубах, чему были как объективные, так и субъективные причины. Москалев собрал поистине уникальный коллектив единомышленников, рассчитал и построил в ВГУ свою, воронежскую аэродинамическую трубу, и стал фактически одним из ведущих в мире теоретиков и экспериментаторов в области аэродинамики. Его разработки в этой области, к сожалению, и сейчас не очень широко известны, а ведь именно Москалевым задолго до Великой Отечественной войны впервые в мире был создан экспериментальный самолет стреловидной формы с крылом малого удлинения, явившийся прообразом самых современных сверхзвуковых летательных аппаратов. Более того, сегодняшние обширные дебаты по определению облика российского перспективного авиационного комплекса Дальней авиации (ПАК ДА) показывают, насколько современны довоенные исследования А. С. Москалева [17]

Александр Сергеевич Москалев, умея по-настоящему мечтать и заглядывать на годы вперед, по инженерному расчетливо, «твердо стоял на ногах», умел трезво оценивать обстановку и использовать малейшие шансы в решении сложнейших (мирового уровня) задач, поставленных перед собой и коллективом.

В Центральной черноземной области и ее столице - г. Воронеже - в 1930-1941 гг. был сформирован крупнейший авиационный комплекс: аэродромная инфраструктура, самолетостроение, моторостроение; производство комплектующих радиостанций, шин для колес шасси; подготовка 
летно-технических кадров в авиационных войсковых частях и учебных заведениях, включая аэроклуб Осоавиахима. Этот комплекс сыграл большую роль в укреплении обороноспособности CССР. Такая огромная по масштабам и значимости работа была по достоинству оценена руководством страны: в 1935 г. Воронежская область была удостоена высшей награды - ордена Ленина [6, с. 26-29].

Даже на фоне такой, поистине титанической по размаху и скорости, стройки, деятельность Александра Сергеевича Москалева обретает особый смысл и масштаб. Именно А. С. Москалев и был тем самым «человеком эпохи Возрождения» отечественной авиации, который оставил свой значимый след в развитии авиационной науки и образования, конструировании самых перспективных образцов летательных аппаратов, совершенствовании отечественного самолето- и двигателестроения. Опередив мировую техническую мысль на несколько десятилетий, А. С. Москалев проложил своими исследованиями дорогу к сверхзвуковым и космическим полетам, тем самым закрепив за Воронежем славу одной из величайших авиационных столиц мира [4, с. 123-129]

Космические достижения нашей страны, если быть принципиальными и последовательными патриотами и исследователями в области орбитальных воздушно-космических самолетов, при всем уважении к научным достижениям К. Э. Циолковского, опираются на мощный не только теоретический, но и практический фундамент, заложенный А. С. Москалевым. Его идея строить самолеты - летающие крылья, в плане напоминающие артиллерийские снаряды (в 1930-е гг. еще не было сверхзвуковых аэродинамических труб и Александр Сергеевич более чем остроумно использовал для своих работ опубликованные в Германии экспериментальные данные об аэродинамике артиллерийских крупнокалиберных снарядов фирмы Круппа), им же - Москалевым была доведена до реального воплощения [2, с. 80]. Сначала в Воронежском университете, где наш герой в период 1933-1936 гг. вел большую научно-исследовательскую работу и одновременно преподавал конструкцию и аэродинамику самолета на кафредре аэромеханики, после пуска аэродинамической трубы (руководитель постройки А. В. Столяров) Москалевым был разработан эскизный проект самолета «Сигма» (САМ-4, 1934 г.) с дельтавидным крылом, а затем - экспериментального истребителя-перехватчика САМ-7 с крылом малого удлинения.

Столичные специалисты, вслед за начальником опытного отдела НКАП И. И. Машкевичем, обвинили А. С. Москалева в «несусветной экзотике», несмотря на то, что проект закреплял за СССР приоритет в открытии новой перспективной компоновки крыла - Александр Сергеевич это особенно подчеркивал [5, с. 29-36]

Гениальный конструктор не был услышан, но работ не прекратил и 8 августа 1937 г. в Воронеже, недалеко от Задонского шоссе, совершил первый полет самолет САМ-9 «Стрела». Пилотировал этот первенец - прямой прототип будущих воздушно-космических самолетов «Буран» и «Шаттл» - летчик-испытатель А. Н. Гусаров. Испытания были продолжены в Москве. САМ-9 "Стрела» продемонстрировал прекрасные летные качества и управляемость [20, с. 67-81]

В дальнейшем судьба как бы специально свела А. С. Москалева с конструктором первого отечественного истребителя БИ-1 с жидкостным реактивным двигателем В. Ф. Болховитиновым, так как из Москвы пришло указание москалевскому заводу в Заводоуковске серийно строить планеры БИ-1: новая космическая эра зарождалась в полные лишений годы Великой Отечественной войны.

Анализируя просчеты и недостатки БИ-1, А. С. Москалев создал проект реактивного истребителя РМ-1 (ракетный Москалев - первый) с двигателем от БИ-1 конструкции А. Душкина, который (и авторские расчеты были многократно подтверждены) в 1945 г. мог бы развивать скорость более $2000 \mathrm{kм} / 4 а \mathrm{l}$ ! Этот самолет обеспечил бы СССР мировое превосходство в скорости минимум на 15 лет. И снова бесконечные хлопоты и попытки пробиться встречали недоверие и непонимание, оговоры и прямой саботаж. Ситуацию отягили аресты наркома Шахурина, а затем и председателя Госплана Вознесенского, давших добро на постройку небывалого во всех отношениях самолета [20, с. 133-140]

Прирожденный аэродинамик-практик, опальный А. С. Москалев (после послевоенного разгрома его ОКБ и ликвидации завода) сначала работал главным инженером ленинградского троллейбусного завода, а затем проводил в Академии им. Можайского большую и сверхсекретную научно-исследовательскую работу по расчетам перспективных компоновок сверхзвуковых тяжелых дальних бомбардировщиков и ракетоносцев. Именно он обеспечил теоретическую базу для создания таких этапных советских самолетов, как сверхзвуковой бомбардировщик В. Мясищева М-50, стратегический разведчик разработки Р. Бисновата, проектов Р. Бартини и, наконец, сверхзвуковых бомбардировщиков ОКБ Туполева Ту-22M3 и Ту-160 [33, с. 4-6].

От маленькой франерной “Стрелы» Москалева образца 1937 г. логика развития конструкторской мысли легко перебрасывает «мостик» к американскому проекту ракетоплана «Дайна Сор», а от него сначала к нашему первому «орбитальному ответу", в котором принимал участие первый космонавт планеты Ю. А. Гагарин, будучи слушателем академии им. Жуковского, а затем - к «Шаттлу». Есть высшая справедливость в том, что наш советский воздушно-космический самолет «Буран» хотя и стал только ответом на американский «Челнок», однако был значительно эффективнее, мощнее и гораздо экологичнее за счет кислородно-водородных двигателей разгонной ступени. Недаром Главный конструктор «Бурана» Глеб Лозино-Лозинский не только не скры- 
вал, но и всегда всячески подчеркивал авторство идеи воздушно-космического орбитального самолета А. С. Москалева, изложенной в его проекте, созданном в 1950-е гт., который назывался САМXXI «Лебедь» [12]

У А. С. Москалева совсем немного государственных наград, но есть одна весьма для него значимая - медаль «Партизанская Слава». Ее вручили Александру Сергеевичу за спасение члена Политбюро А. Щербакова. Когда партизанский отряд, в котором А. Щербаков был с инспекцией окружили гитлеровские карательные части, эвакуировать его смогли лишь благодаря выдающимся взлетно-посадочным характеристикам небольшого и легкого многоцелевого самолета конструкции Москалева САМ-25, позволившие пилоту приземлиться и успешно взлететь с маленькой лесной поляны [20, с. 127].

Таким образом, основные результаты деятельности А. С. Москалева аргументированно под- тверждают, что он является настоящим гением отечественной школы самолетостроения. Реализация его проектов 1930-х гг. в серийном масштабе позволила бы не только сэкономить в значительных размерах финансовые и материальные ресурсы, в которых страна испытывала большой дефицит, но и значительно способствовала бы укреплению оборонной мощи Советского Союза, так как самолеты Москалева превосходили по тактико-техническим характеристикам, по дальности и скорости полета лучшие как отечественные, так и зарубежные образцы. Но этого не произошло по ряду в основном субъективных причин, не зависящим от авиаконструктора.

А. С. Москалев внес значительный вклад и в развитие авиационной науки, идеи которого до сих пор используются при создании сверхзвуковой и гиперзвуковой авиации, а также воздушно-космических самолетов.

\section{Источники и литература}

1. Авиационный двигатель М-11ФР. Инструкция по техническому обслуживанию. М.: Оборонгиз, 1953. 108 с.

2. Бауэрс П. Летательные аппараты нетрадиционных схем. М.: Мир, 1991. 320 с.

3. Виноградов Р. И., Пономарев А. Н. Развитие самолетов мира. М.: Машиностроение, 1991. 384 с

4. Воронеж. История края в его музеях. М.: Polarees, 2007. 132 с.

5. Гагин В. В. Авиаконструктор А. С. Москалев. 1904-1982. К 95-летию со дня рождения. Воронеж: Полиграф, 1999. $80 \mathrm{c}$.

6. Гагин В. В. Самолеты Воронежского Авиационного завода. Воронеж: НПП «Траст», 1996. 88 с

7. ГАРФ. Ф.Р-8355. ОП. 5. Д. 15.

8. ГАРФ. Ф.Р-8355. Оп. 5. Д. 43

9. ГАРФ. Ф.Р-8355. ОП. 6. Д. 16

10. Гугля Ю. Последние истребители Поликарпова. И-180, И-185. Киев: Архив-Пресс. 1998. 46 с.

11. Дузь П. Д. История воздухоплавания и авиации в России. М.: Машиностроение, 1989. $336 \mathrm{c}$.

12. Ермолов С. Конверсия - не ломка... О Г. Лозино-Лозинском // Наши Крылья. 1991. №1. 62 с.

13. Знаменский В. А. Воспоминания. Рукопись. 1999. Архив автора.

14. Иванов В. П. Авиаконструктор Н. Н. Поликарпов. СПб.: Политехника, 1995. 223 с.

15. История истребительной авиации с 1916 по 2016 гг. К 100-летию истребительной авиации России. Воронеж: Научная книга, 2017. 396 с.

16. Катышев Г. И. Михеев В. Р. Крылья Сикорского. М.: Воениздат, 1992. 432 с.

17. Ковалев М. А. О расчете и исследовании аэродинамических труб // Ученые записки ЛГУ. 1939. №42. $138 \mathrm{c.}$

18. Краеведческая конференция «Наше наследие»: материалы докладов и сообщений / под ред. Р. Г. Назаровой, л. И. Басова. Заводоуковск: б.и., 2012. 134 с.

19. Красильщиков А. П. Планеры СССР: справочник. М.: Машиностроение, 1991. 240 с.

20. Москалев А. С. Голубая спираль. Автобиографическая повесть. Воронеж: ЦЧКИ, 1995. 160 с.

21. Небывалые достижения Воронежского аэрокосмического комплекса. Вестник воздухоплавания, авиации и ракетостроения. Воронеж: ИЛДВА, 2005. 16 с.

22. Пинчук В. М. Деятельность коммунистической партии по подготовке и воспитанию инженерно-технических кадров Военно-Воздушных сил в годы довоенных пятилеток. (1929-1941 гг.): дисс. ... канд. ист. наук. М.: ВВИА им. проф. Н. Е. Жуковского, 1974. 200 c.

23. Пономарев А. Н. Советские авиационные конструкторы. М.: Воениздат, 1980. 47 с.

24. Растренин О. Штурмовики Великой Отечественной войны. М.: Яуза, 2008. 396 с.

25. Российский государственный военный архив (далее - РГВА). Ф. 4. Оп. 4. Д. 1578.

26. РГВА. Ф. 35082 . ОП. 1. Д. 2.

27. РГВА. Ф. 37977. Оп. 4. Д. 322.

28. Савин В. Планета «Константин». Харьков: Основа, 1994. 312 с.

29 Самойлович О. Рядом с Сухим (Воспоминания авиационного конструктора). М.: От винта!, 1999. 136 с.

30. Самолетостроение в СССР 1917-1945 гг. Книга 1. М.: ЦАГИ, 1992. 438 с.

31. Султанов И. Конкурс канул в небытие // Крылья Родины. 1993. №10.

32. Техническое описание самолета У-2 с мотором М-11. Описание конструкции самолета. Часть 1. М., Л.: Завод №23, $1937.252 \mathrm{c}$.

33. Тяжелые бомбардировщики // Невский Бастион. 1994. Вып. №5. 1994. 48 с.

34. Шавров В. Б. История конструкций самолетов в СССР до 1938 г. М.: Машиностроение, 1994. 704 с.

35. Уголок неба. URL: airwar.ru/enc/cw1/sam5/html. (Дата обращения: 23.09.2017).

36. Mosquito Special // Fly Past. 2014. August. P. 41-59. 


\section{References}

1. Aviatsionnyy dvigatel' M-11FR. Instruktsiya po tekhnicheskomu obsluzhivaniyu (Aircraft engine M-11FR. Maintenance Instructions). Moscow: Oborongiz publ., 1953. 108 p. (In Russian)

2. Bauers P. Letatel'nye apparaty netraditsionnykh skhem (Aircraft unconventional schemes). Moscow: Mir publ., 1991. 320 p. (In Russian)

3. Vinogradov R. I., Ponomarev A. N. Razvitie samoletov mira (The development of the world's aircraft). Moscow: Mashinostroenie publ., 1991. 384 p. (In Russian)

4. Voronezh. Istoriya kraya v ego muzeyakh (Voronezh. The history of the region in its museums). Moscow: Polarees publ. 2007. 132 p. (In Russian)

5. Gagin V. V. Aviakonstruktor A.S. Moskalev. 1904-1982. K95-letiyu so dnya rozhdeniya (Aircraft Designer A.S. Moskalev) Voronezh: Poligraph, 1999. 80 p. (In Russian)

6. Gagin V. V. Samolety Voronezhskogo Aviatsionnogo zavoda (Aircraft of the Voronezh Aviation Plant). Voronezh: NPP «Trast» publ., 1996. 88 p. (In Russian)

7. State archive of Russian Federation (GARF). F.R-8355. Inv. 5. D. 15. (In Russian)

8. GARF. F.R-8355. Inv. 5. D. 43. (In Russian)

9. GARF. F.R-8355. Inv. 6. D. 16. (In Russian)

10. Guglya Yu. Poslednie istrebiteli Polikarpova. I-180, I-185 (The last fighters Polikarpov. I-180, I-185). Kiev: Arkhiv-Press publ., 1998. 46 p. (In Russian)

11. Duz' P. D. Istoriya vozdukhoplavaniya i aviatsii v Rossii (The history of aeronautics and aviation in Russia). Moscow: Mashinostroenie publ., 1989. 336 p. (In Russian)

12. Ermolov S. Konversiya - ne lomka... O G. Lozino-Lozinskom (Conversion-not breaking ... About G. Lozino-Lozinsky) // Nashi Kryl'ya. 1991. No. 1. (In Russian)

13. Znamenskiy V. A. Vospominaniya. Rukopis' (Memories. Manuscript). 1999. Arkhiv avtora. (In Russian)

14. Ivanov V. P. Aviakonstruktor N. N. Polikarpov (Aircraft designer N. N. Polikarpov). St. Petersburg: Politekhnika publ. 1995. 223 p. (In Russian)

15. Istoriya istrebitel'noy aviatsii s 1916 po $2016 \mathrm{gg}$. K 100-letiyu istrebitel'noy aviatsii Rossii (The history of fighter aircraft from 1916 to 2016. To the 100th anniversary of Russian fighter aviation). Voronezh, 2017. $396 \mathrm{p}$. (In Russian)

16. Katyshev G. I. Mikheev V. R. Kryl'ya Sikorskogo (Wings of Sikorsky). Moscow: Voenizdat publ., 1992. 432 p. (In Russian)

17. Kovalev M. A. O raschete $\mathrm{i}$ issledovanii aerodinamicheskikh trub (On calculation and research of wind tunne/s) /I Uchenye zapiski LGU. 1939. No. 42. (In Russian)

18. Kraevedcheskaya konferentsiya «Nashe nasledie»: materialy dokladov i soobshcheniy (Local Lore Conference "Our Heritage ": materials of reports and messages) / ed by R. G. Nazarova, L. I. Basov. Zavodoukovsk, 2012. 134. (In Russian).

19. Krasil'shchikov A. P. Planery SSSR: spravochnik (Gliders of the USSR: a guide). Moscow: Mashinostroenie publ. 1991. 240 p. (In Russian)

20. Moskalev A. S. Golubaya spiral'. Avtobiograficheskaya povest' (Blue spiral. Autobiographical story). Voronezh: TsChK publ., 1995. 160 p. (In Russian)

21. Nebyvalye dostizheniya Voronezhskogo aerokosmicheskogo kompleksa. Vestnik vozdukhoplavaniya, aviatsii raketostroeniya (The unprecedented achievements of the Voronezh aerospace complex. Bulletin of aeronautics, aviation and rocket science). Voronezh: ILDVA publ., 2005. 16 p. (In Russian)

22. Pinchuk V. M. Deyatel'nost' kommunisticheskoy partii po podgotovke i vospitaniyu inzhenerno-tekhnicheskikh kadrov Voenno-Vozdushnykh sil v gody dovoennykh pyatiletok. (1929-1941 gg.) (The activities of the Communist Party in the training and education of engineering personnel of the Air Force during the prewar five-year periods. (1929-1941): thesis. Moscow: VVIA named after N. E. Zhukovskii publ., 1974. 200 s. (In Russian)

23. Ponomarev A. N. Sovetskie aviatsionnye konstruktory (Soviet aviation designers). Moscow: Voenizdat publ., 1980. $47 \mathrm{p}$ (In Russian)

24. Rastrenin O. Shturmoviki Velikoy Otechestvennoy voyny (Attack aircraft of the Great Patriotic War). Moscow: Yauza publ., 2008. 396 p. (In Russian)

25. Russian state military archive (RGVA). F.4. Inv. 4. D.1578. (In Russian)

26. RGVA. F. 35082. Inv. 1. D.2s. (In Russian)

27. RGVA. F. 37977. Inv. 4. D. 322. (In Russian)

28. Savin V. Planeta «Konstantin» (Planet "Constantine»). Khar'kov: Osnova publ., 1994. 312 p. (In Russian)

29 Samoylovich O. Ryadom s Sukhim (Vospominaniya aviatsionnogo konstruktora) (Near Sukhoi (Memoirs of an aircraft designer). Moscow: Ot vinta! Publ., 1999. 136 p. (In Russian)

30. Samoletostroenie v SSSR 1917-1945 gg. (Aircraft manufacturing in the USSR 1917-1945). Book 1. Moscow: TsAGI publ., 1992. 438 p. (In Russian)

31. Sultanov I. Konkurs kanul v nebytie (The contest sunk into oblivion) // Kryl'ya Rodiny. 1993. No. 10. (In Russian)

32. Tekhnicheskoe opisanie samoleta U-2 s motorom M-11. Opisanie konstruktsii samoleta. Chast' 1. (Technical description of the U-2 aircraft with the M-11 engine. Description of the design of the aircraft. Part 1). Moscow, Leningrad: Zavod №23 publ., 1937. 252 p. (In Russian)

33. Tyazhelye bombardirovshchiki (Heavy bombers) // Nevskiy Bastion. 1994. Issue. No.5. 1994. (In Russian)

34. Shavrov V. B. Istoriya konstruktsiy samoletov v SSSR do $1938 \mathrm{~g}$. (The history of aircraft structures in the USSR until 1938). Moscow: Mashinostroenie, 1994. 704 p. (In Russian)

35. Ugolok neba (Corner of the sky). URL: airwar.ru/enc/cw1/sam5/html. (Accessed: 23.09.2017). (In Russian)

36. Mosquito Special // Fly Past. 2014. August. P. 41-59. 


\section{Сведения об авторе}

Гагин Владимир Владимирович - кандидат исторических наук, старший научный сотрудник Военно-учебного научного центра Военно-воздушной академии им. проф. Н. Е. Жуковского и Ю. А. Гагарина, председатель Воронежского Русского военно-исторического общества (г. Воронеж) / vrvio@yandex.ru

\section{Information about the author}

Gagin Vladimir - PhD in History, Senior Researcher, Military Research Center of the Air Force of the Air Force named after N. Zhukovsky and Yu. Gagarin, Chairman of the Voronezh Russian Military Historical Society (Voronezh) / vrvio@yandex.ru 